\title{
Entrepreneurial universities and regional contribution
}

\author{
Natalia Budyldina ${ }^{1,2}$ (D)
}

Published online: 29 March 2018

(C) The Author(s) 2018

\begin{abstract}
For the past few decades, higher education institutions (HEIs) have been evolving into full-fledged managerial entities preoccupied with generating profits and creating an economic impact on local, regional and national scales. Taking cues from the international trend, numerous political initiatives in Russia have emphasized government support for innovative and entrepreneurial activities at regional universities. This study attempts to define the dimensions of entrepreneurial universities and determine to what extent this definition is applicable to the regional context in Russia. Using data from HEIs' efficiency monitoring conducted by the Ministry of Education and the Science of Russian Federation, we analyze the scientific and research productivity metrics and the funding structure of 20 universities located in the Saint Petersburg region, and we investigate the entrepreneurial activities undertaken by different types of universities. While policymakers and universities tend to employ mostly quantitative quality performance indicators (QPIs) to capture scientific productivity and commercial outcomes, the findings suggest that the regionalized impact of universities extends far beyond technology transfer and tangible outputs (in terms of human capital attraction and detention, formation of entrepreneurship capital, informal networks, new ideas, etc.). This study furthers the knowledge about the heterogeneous nature of entrepreneurialism at Russian universities and provides useful insights for policymaking and managerial practice. The transformation of a university into a local entrepreneurial fulcrum demands massive government funding during the initial stages and coordinated policy measures to foster the innovative activities of the university without compromising its traditional teaching and research functions.
\end{abstract}

Keywords Entrepreneurial university · Regional innovation systems · Technology transfer Academic entrepreneurship

Natalia Budyldina

n.budyldina@hse.ru

1 Higher School of Economics-Saint-Petersburg Campus, 3A, Kantemirovskaya St, 194100 Saint-Petersburg, Russia

2 University of Manchester, Manchester, UK 


\section{Introduction}

The perception of higher education institutions (HEIs) as engines for regional growth has long captured the attention of scholars and policymakers, and the 'Triple Helix' model has marked universities' departure from 'ivory towers' to proactive entrepreneurial entities. In addition to their traditional teaching and research functions, universities engage in technology transfer, establish links with industry and facilitate the creation of innovation infrastructure, i.e., research laboratories, science parks and industry clusters. Thus, for the past few decades, universities have been evolving into fully fledged managerial organizations preoccupied with generating profits and creating an economic impact on local, regional and national scales.

One of the major theoretical premises of HEIs' ever-increasing involvement in entrepreneurial activities is the knowledge spillover theory of entrepreneurship. According to this theory, firms and individuals might capitalize on locating in geographic proximity to major sources of knowledge spillovers (large corporations and public research institutions), which fail to fully appropriate new commercial ideas and opportunities (Audretsch and Lehmann 2005; Audretsch et al. 2012). Much emphasis has been placed on knowledge-generating institutions that contribute to innovation processes via localized knowledge spillovers (technology transfer and labor force transition) and the creation of 'entrepreneurship capital' within a locale (Guerrero et al. 2014). Furthermore, the gradual transition to an open innovation mode has rendered inhouse research less effective than networking activities and cooperative extramural $\mathrm{R} \& \mathrm{D}$, while universities have accrued more power as knowledge institutions critical for regional development (Allison and Eversole 2008).

Although the promotion of entrepreneurial activities within HEIs is usually associated with external stimuli such as national legislature and science and technology (S\&T) policies, the increased engagement of universities in national and regional innovation systems has multiple positive effects for micro- and macroeconomic development. Apart from immediate outputs of academic research commercialization (circumscribed to a few high-tech industries as a rule of thumb), universities act as 'anchor tenants' attracting human capital and innovative firms to the locale. Due to the relative nascency of the research area and the limited data sources, evidence of HEIs' localized economic impact is mixed and varies with the locale, the specialization of the university in question and the type of data employed. Nevertheless, positive long-term effects of 'third-stream' activities undertaken by universities have been documented in terms of skilled employment, average incomes, regional GDP per capita and new firm creation. ${ }^{1}$

Taking cues from the international trend, umpteen political initiatives in Russia have emphasized government support aimed at augmenting the 'innovativeness' of universities and local industry and the promotion of entrepreneurial activities within the former. Moreover, intense publication and R\&D requirements, higher salaries demanded by academic staff and student mobility have rendered it unsustainable for universities to engage purely in teaching functions. While the higher education system in Russia is generally regulated on the national level, the downward dynamics of federal funding are still likely to put pressure on regional universities due to severe competition on the national education 'financial' market. Middling HEIs that find it

\footnotetext{
${ }^{1}$ See Bonander et al. (2016) for a review.
} 
tough to vie for grant and contest funding with larger and metropolitan universities are pressed to seek non-budgetary sources, and they are more likely to pursue links with industry on a local scale due to so-called 'soft' factors, i.e., established formal and informal contacts and societal accountability issues (Ankrah and Al-Tabbaa 2015).

At the same time, the efficiency of budgetary capital investments in selected Russian higher education institutions has been subject to considerable scrutiny lately. Massive government funding of selected universities distorts the entrepreneurial motivation of academic staff, while publication and citation indices are employed as major quality performance indicators (QPIs). This is likely to shift the focus away from commercialization activities; universities and academicians generally fail to perceive technology transfer as a source of monetary income and employ new patents and spin-offs to secure additional grant funding (Russian Venture Company 2015). Moreover, local business in Russia is hesitant to establish commercial ties with universities due to the lack of proper intellectual property (IP) rights and royalty distribution mechanisms, so there is no evident interest on behalf of both parties in the commercialization of academic research results and technology transfer.

This paper thus attempts to define the dimensions of entrepreneurial universities and determine to what extent this notion is applicable to the Russian regional context. Using open access data from HEIs' websites, we investigate the types of entrepreneurial activities undertaken by selected universities located in the Saint Petersburg region and select universities based on a broad range of formal and informal entrepreneurial activities, including technology transfer, contract research, public events and entrepreneurial mission statement. First, selected universities are assigned to three groups according to their entrepreneurial stance: potentially entrepreneurial, adaptive entrepreneurial and an ideal type. Second, we analyze the average group metrics of scientific and research productivity and funding structure and look into whether the nature of entrepreneurialism at selected universities is in accordance with the broader literature. The findings suggest that the impact of entrepreneurial universities on a regional scale extends far beyond commercial and tangible outputs, while a simple cost-benefit analysis fails to capture indirect and less tangible outcomes (in terms of human capital attraction and detention, formation of entrepreneurship capital, informal networks, new ideas, etc.). The transformation of a university into a local entrepreneurial fulcrum, therefore, demands massive government funding at the initial stages and coordinated policy measures aimed at augmenting collaborative activities between industrial organizations and higher education institutions within a home region.

This paper proceeds with a brief literature review elaborating on the modern concept of an entrepreneurial university and providing a regionalized perspective on academic entrepreneurial activities. In the following section, the methodology and data employed in the research are presented, followed by a quantitative data analysis of selected universities and a discussion of the major findings. The last part concludes with some directions for further research and policy implications.

\section{Regionalized perspective}

One of the first regionalized theoretical models of entrepreneurial university, called the 'Triple Helix' model, was coined by H. Etzkowitz. The model is premised on 
successful practices of academic research commercialization in high-tech areas of expertise, with Stanford University and Massachusetts Institute of Technology as prominent examples. According to Etzkowitz, a major feature of an entrepreneurial university is the commercialization of research results via the creation of contiguous 'hybrid structures' with the state and industry (Etzkowitz 2016; Schmitz et al. 2017). The applicability of the model, however, is circumscribed to industries with higher absorptive capacity or, in a regionalized case, to local firms that are capable of commercializing complex academic research results. In another conceptualization of entrepreneurial universities, B. Clark based his model on European and British universities and extended Etzkowitz's vision to the qualitative characteristics of universities (Clark 1998). Apart from profit-oriented activities (i.e., a diversified funding base), Clark highlighted strategic and managerial flexibility, autonomous decision-making and integrated entrepreneurial culture within universities (Shattock 2010).

Though a unilateral approach to defining entrepreneurial university is still missing, most related papers highlight the same features: the development of 'third mission' activities, i.e., technology transfer and university-industry links, and the contributions to regions, both tangible (new job creation and revenue generation) and intangible (shaping of entrepreneurial mindsets and innovative culture in society). Table 1 provides selected definitions of the entrepreneurial university that are acknowledged in related literature.

As defined by Urbano and Guerrero (2013, p. 43), 'entrepreneurial university needs to become an entrepreneurial organization, its members need to become entrepreneurs, and its interaction with the environment needs to follow an entrepreneurial pattern'. Thus, not unlike competitive firms, universities accumulate available resources (academic staff, students, financial resources and networks) and employ strategic management tools to commercialize academic knowledge via spinning off companies, selling research results to industrial organizations and undertaking contract research (Liu 2012; Trippl et al. 2015). Entrepreneurial universities seek to employ commercial opportunities (Kirby et al. 2011), and while links with an industrial or commercial association are considered crucial (Taylor 2012; Schmitz et al. 2017), universities also produce less tangible outcomes. They act as forerunners of entrepreneurial thinking, provide leadership for corresponding actions and disseminate this mindset within its walls as well as in wider society (Audretsch 2014). At the same time, most scholars acknowledge that demand-driven innovation has put pressure on universities to improve the quality of academic research and comply with industry standards. Therefore, entrepreneurial universities seek to attract qualified academic and managerial staff, associates and students, and they have to maintain a certain reputation to be able to do so (Guerrero and Urbano 2012).

Despite obviously varying approaches to defining an entrepreneurial university - be it the quality and commercial value of academic research, strategic approaches to management, diversification of the funding base or the promotion of entrepreneurial culture - most related studies highlight the regionalized nature of HEIs' socioeconomic impact and exemplify them first and foremost as regional actors (Trippl et al. 2015; Etzkowitz 2016).

The increased engagement of higher education institutions in regional and local innovation systems was prompted by the process of governance devolution in developed nations; the European Union is but one prominent example. Since regions have accrued more institutional and economic autonomy, innovative development on behalf of universities has been increasingly embraced by local authorities, especially in 
Table 1 Definitions of entrepreneurial university

\begin{tabular}{|c|c|}
\hline Paper & Definition of entrepreneurial university \\
\hline $\begin{array}{l}\text { Urbano and Guerrero } \\
\text { (2013) }\end{array}$ & $\begin{array}{l}\text { '[E]ntrepreneurial university needs to become an } \\
\text { entrepreneurial organization, its members need to become } \\
\text { entrepreneurs, and its interaction with the environment needs } \\
\text { to follow an entrepreneurial pattern' }\end{array}$ \\
\hline Guerrero et al. (2014) & $\begin{array}{l}\text { 'The nature of an entrepreneurial university is such that graduates } \\
\text { are perceived not only as future job-seekers but also as future } \\
\text { job-creators, } \\
\text { and the organization and content of teaching activities reflects } \\
\text { this conception' }\end{array}$ \\
\hline $\begin{array}{l}\text { Guerrero and Urbano } \\
\text { (2012) }\end{array}$ & $\begin{array}{l}\text { '[A]n entrepreneurial university could be defined as a survivor of } \\
\text { competitive environments with a common strategy oriented to } \\
\text { being the best in all its } \\
\text { activities (e.g., having good finances, selecting good students } \\
\text { and teachers, producing quality research)' }\end{array}$ \\
\hline Kirby et al. (2011) & $\begin{array}{l}\text { '[E]ntrepreneurial university is a natural incubator that, by adopting } \\
\text { a coordinated strategy across critical activities (e.g., teaching, research } \\
\text { and entrepreneurship), tries to provide an adequate atmosphere in which } \\
\text { the university community } \\
\text { (e.g., academics, students and staff) can explore, evaluate and exploit } \\
\text { ideas that could be transformed into social and economic entrepreneurial } \\
\text { initiatives' }\end{array}$ \\
\hline Taylor (2012) & $\begin{array}{l}\text { '[E]ntrepreneurial in the broad sense of generating a growing percentage } \\
\text { of funding from non-state sources or linking more closely to society } \\
\text { through third-stream activity with an industrial or commercial association' }\end{array}$ \\
\hline Audretsch et al. (2012) & $\begin{array}{l}\text { '[T]he role of universities is more than generating technology transfer } \\
\text { (patents, spin-offs and start-ups), and rather, contribute and provide } \\
\text { leadership for creating entrepreneurial thinking, actions, institutions } \\
\text { and entrepreneurial capital' }\end{array}$ \\
\hline Liu (2012) & $\begin{array}{l}\text { 'The entrepreneurial university model originated in the process of the } \\
\text { utility of knowledge to industry, in which substantial returns will } \\
\text { be gained } \\
\text { through selling knowledge' }\end{array}$ \\
\hline Trippl et al. (2015) & $\begin{array}{l}\text { 'The entrepreneurial model claims that universities promote the } \\
\text { development of their regions by engaging in patenting, licensing } \\
\text { and academic spin-off activities, generated from university subjects } \\
\text { such as engineering, information technology and biotechnology, } \\
\text { in which the knowledge produced overlaps more readily with } \\
\text { products and processes that industry and market structures can absorb' }\end{array}$ \\
\hline Etzkowitz (2016) & ' $[\mathrm{T}]$ he entrepreneurial university is first and foremost a regional actor' \\
\hline
\end{tabular}

economically troubled regions or those undergoing industrial restructuring, such as Wales and Scotland in the United Kingdom, Southern Italy, Andalusia in Spain and the Värmland region in Sweden, among others (Ramos-Vielba et al. 2010; Huggins and Kitagawa 2012; Cowan and Zinovyeva 2013; Kempton 2015).

HEIs' involvement in regional economies stems from personal and informal contacts, which are a powerful source of academic knowledge transfer to private firms, while spatial co-location plays a prominent role by facilitating the creation of university-industry links (UIL). Considerable anecdotal evidence from developed and developing countries alike demonstrates HEIs' engagement with business and 
authorities on the subnational level. Some authors on the demand side advocate for shared cultural values and historically established cooperative ties between universities and industry over spatial co-location, but empirical evidence still suggests that innovative firms are more likely to source knowledge from local HEIs. Indeed, the number of technological start-ups is positively correlated with (though not ascribed to) the spatial proximity of universities, while academic spin-offs have a strong 'alma mater bias' (Russian Venture Company 2015; Carree et al. 2015).

HEIs' economic impact is also extremely regionalized in terms of (high-skilled) employment and the provision and training of human capital for the regional economy. Up to $80 \%$ of university graduates in Russia, for instance, are employed within the same macro-region where they obtained their degrees, while for less developed regions, the share drops to approximately 50\% (Ministry of Education and Science of Russian Federation 2016). A regional outlook, then, makes sense and provides a functional framework for the explication of universities' collaborative and commercialization activities.

The Saint Petersburg city-region is a good place to start looking into entrepreneurial universities in Russia due to its developed industrial stance, prominent position in national rankings of innovative activity and long-established cooperation between industry and local research universities. Tapping into the pool of skilled human capital is made easier by ongoing immigration (the federal status and prestige of Saint Petersburg are comparable to those of Moscow) and the outstanding education quality at local universities. The region boasts three HEIs participating in the national 'Project 5-100', aimed at augmenting the research potential and third-stream activities of selected Russian universities.

\section{Methodology and data}

The methodology in the remainder of this paper consists of two parts. The qualitative part is premised on the content review of universities' official websites and open access data regarding their entrepreneurial and innovative activities, including mission statements and related strategic documents. According to different approaches, a broad range of formal and informal entrepreneurial practices are considered in order to select entrepreneurial universities located in the Saint Petersburg region. Thus, for the purposes of this paper, universities in the final sample comply with at least one of four major criteria of an entrepreneurial university highlighted in the theoretical part: (1) quality of research, proxied by the presence of innovation infrastructure (business incubators, technology transfer offices, test facilities, etc.), (2) extensive networking - participation in regional innovation policy initiatives, such as regional innovation clusters (selected HEIs are active participants in the high-tech and engineering cluster and the biopharmaceutical cluster; many of them share research facilities with regional industrial organizations), (3) diversification of income sources - established university-industry links (strategic partnership initiatives, contract research, license fees, etc.) and (4) creation of entrepreneurship capital, or the manifestation of entrepreneurial missions in official university documents and otherwise active promotion of entrepreneurial initiatives in the region.

The quantitative side relates to the analysis of individual HEIs' research and innovation performance. HEI-level data for 2016 are collected from HEIs' efficiency monitoring data, conducted and made freely available by the Ministry of Education and the Science of Russian Federation. Available quantitative indicators of HEIs' entrepreneurial 
performance capture scientific and research productivity (publication activity, amount of contract research and R\&D incomes) and financial independence (share of non-budget funding, including non-budget R\&D funding), while qualitative characteristics measure the overall entrepreneurial stance of a university (spin-offs, innovation infrastructure, entrepreneurial mission statement, etc.).

\section{Entrepreneurial universities in Saint Petersburg}

Of approximately 70 higher education institutions located in Saint Petersburg, only 20 satisfy at least one of the abovementioned qualitative criteria and can be characterized as entrepreneurial. Based on the four criteria, the universities in the final sample can be classified into three major entrepreneurial types: a potentially entrepreneurial (researchintensive) university, an adaptive entrepreneurial university and an ideal entrepreneurial type of university. The classification is based on an appropriation of Yokoyama's (2006) theoretical framework, which assigns universities to five major types, ranging from a prototype to an ideal type of entrepreneurial university.

(I) The potentially entrepreneurial group in the sample is represented by polytechnic and industrial universities with developed scientific and research bases and academic excellence in certain areas of scientific research. Universities in the group tend to have a long history of collaboration with industry inherited from former Soviet sectoral research institutes; they engage in both formal and informal entrepreneurial activities (predominantly on the regional scale) but preserve rigid managerial structures and are less focused on becoming entrepreneurial per se. (II) The adaptive entrepreneurial type is more market-oriented in focus, has established innovation infrastructure and is moving towards independence from budgetary funding. Adaptive entrepreneurial universities actively seek to establish Etzkowitz's hybrid structures with regional stakeholders, including firms but mostly regional associations and government. (III) Finally, an ideal entrepreneurial type is a fully fledged managerial organization with a diversified funding base; it integrates and promotes entrepreneurial culture throughout all university levels (students, academic and managerial staff) via mission statements, reward schemes and public events (conferences, forums, etc.) as well as beyond university walls.

According to the classification criteria, 10 universities located in Saint Petersburg are defined as potentially entrepreneurial, 5 universities are considered adaptive, and another 5 possess all the prerequisites of an ideal type (Table 2). Classifying universities as a particular type was not unilateral; for instance, St. Petersburg State Transport University retrieves approximately $70 \%$ of its funding from non-budgetary sources and takes the lead in the share of incomes from intellectual property management $(2.96 \%$ of total income and 10 active licensing agreements); it does not, however, have its own commercialization infrastructure (technology transfer offices, etc.). State University of Maritime and Inland Shipping has no commercialization infrastructure, but the promotion of collaborative activities with industrial organizations and the active support and remuneration of innovative and entrepreneurial activities among students and academic staff are postulated in the university's mission statement. Both universities were therefore assigned to the adaptive entrepreneurial group. 
Table 2 Classification types of entrepreneurial universities in Saint Petersburg

III. Potentially entrepreneurial type II. Adaptive entrepreneurial I. Ideal entrepreneurial type type

1. Saint Petersburg State University of Economics

2. Pushkin Leningrad State University

3. Baltic Academy of Tourism and Entrepreneurship

4. National Research Academic University of Russian Academy of Science

5. European University

6. The Bonch-Bruevich Saint - Petersburg State University of Telecommunications

7. State University of Architecture and Civil Engineering

8. Baltic State Technical University

9. North-Western State Medical

University

10. State Chemistry and

Pharmaceutical Academy
1. Saint Petersburg State University

2. Emperor Alexander I St. Petersburg State Transport University

3. Admiral Makarov State University of Maritime and Inland Shipping

4. State Maritime Technical University

5. State Agrarian University
1. National Research University of Information Technology, Mechanics and Optics

2. State Electrotechnical University

3. State Polytechnic University

4. State Technological Institute

5. State University of Aerospace Instrumentation

\section{Findings}

\section{Scientific and research productivity}

Table 3 provides insights into the scientific and research productivity of universities classified as each type (proxied by publication and citation indices, commercial research income per academic staff and share of R\&D incomes in total) as well as their funding sources (state, business and foreign). Quite predictably, higher publication activity is

Table 3 Group average quantitative indicators of different university types

\begin{tabular}{llll}
\hline Indicator & I & II & III \\
\hline $\begin{array}{l}\text { Publications indexed in Russian Index of Scientific Citation database per 100 } \\
\text { academic staff }\end{array}$ & 139.8 & 139.3 & 186.0 \\
Web of Science and Scopus publications per 100 acad. staff & 90.2 & 24.0 & 36.8 \\
Non-budget incomes in total income, \% & 38.6 & 43.3 & 61.5 \\
Non-budget R\&D incomes in total income, \% & 23.8 & 20.4 & 10.0 \\
Non-budget incomes in total R\&D income, \% & 56.9 & 75.4 & 73.8 \\
International R\&D incomes, thousand rubles & $17,705.9$ & 8173.9 & 4060.5 \\
R\&D incomes per 1 academic staff, thousand rubles & 402.3 & 575.1 & 441.9 \\
Start-ups and spin-offs & 24.4 & 5.6 & 1.7 \\
Total academic staff & 940.6 & 1229.0 & 367.0 \\
Young academic staff (non-PhD under 30 years, PhD under 35 years), \% & 21.5 & 12.1 & 18.4 \\
\hline
\end{tabular}


related to a higher share of non-budgetary R\&D incomes, including business and international funding sources, which is distinctive of potentially entrepreneurial universities. On the one hand, industrial firms tend to consider the quality (and, as a rule of thumb, quantity) of academic research when considering a university as a partner, while on the other hand, close cooperation of academic staff with businesspeople in turn positively affects publication activity (via co-publications, disclosure of research results, etc.). Research quality is thus higher in universities with established UIL.

At the same time, internationalization strategies (proxied by the volume of foreignfinanced $R \& D$ and international publication and citation indices) are more common for universities with a developed 'third mission' (an ideal entrepreneurial type); these are more actively engaged in joint international research projects and academic exchange with foreign universities. International orientation derives from a combination of factors, which include internal stimuli for academic staff as well as the necessity to comply with government directives. The higher international publication activity of type I universities might be attributed to the participation of three universities (National Research University of Information Technology, Mechanics and Optics, State Electrotechnical University and State Polytechnic University) in 'Project 5-100', where international publication and citation indices are employed as major QPIs.

Remarkably, the employment of younger academic staff at type I universities tends to inflate international publication and citation indices due to the extensive language proficiency of the younger generation and the appreciated prestige of international research and engagement with foreign researchers. Otherwise, publication activity is overall more intensive in universities that promote entrepreneurial initiatives and actively engage in technology transfer and regional innovation initiatives, regardless of the type of university (polytechnic, industry-specific or humanitarian).

\section{Funding sources}

Regarding funding sources, type II and III universities tend to diversify more than type I HEIs and generally have a higher share of non-state financing in their total income (Table 4). This is especially true for potentially entrepreneurial polytechnic and industrial universities, for which a higher share of R\&D incomes in total implies a higher share of business-financed R\&D. Industry-specific and technical HEIs prove to be less dependent on public funding; for instance, State Technical University, National Research University of Information Technology, Mechanics and Optics and State Electrotechnical University secure $30-50 \%$ of their incomes from sources other than state funding.

Overall, for the universities in the sample, higher non-budgetary incomes do not guarantee that they have an entrepreneurial stance (most technical HEIs are assigned to the potentially entrepreneurial group). For all entrepreneurial type I HEIs in the sample, state funding accounts for a major income source, especially for three universities that are massively financed by government grants and direct transfers under the aegis of the national priority project ('Project 5-100'). Type I universities also tend to be larger in size (in terms of academic staff) and better equipped with innovation infrastructure due to fewer financial constraints: they exercise a competitive edge over smaller universities when vying for state funding. Moreover, entrepreneurial activities in larger HEIs are prompted by legitimization in the eyes of broader society: the bigger the university, the 
Table 4 Major funding sources of selected entrepreneurial universities

\begin{tabular}{|c|c|c|c|c|}
\hline University & Type & $\begin{array}{l}\text { Non-budget } \\
\text { R\&D incomes in } \\
\text { total income, \% }\end{array}$ & $\begin{array}{l}\text { Non-budget } \\
\text { incomes in total } \\
\text { R\&D income, } \%\end{array}$ & $\begin{array}{l}\text { Non-budget } \\
\text { incomes in total } \\
\text { income, } \%\end{array}$ \\
\hline State Maritime Technical University & II & 47.4 & 98.7 & 63.6 \\
\hline $\begin{array}{l}\text { National Research University of } \\
\text { Information Technology, Mechanics and } \\
\text { Optics }\end{array}$ & I & 39.8 & 34.8 & 28.3 \\
\hline State Electrotechnical University & I & 33.9 & 76.6 & 38.7 \\
\hline $\begin{array}{l}\text { National Research Academic University of } \\
\text { Russian Academy of Science }\end{array}$ & III & 27.8 & 35.7 & 26.9 \\
\hline $\begin{array}{l}\text { Emperor Alexander I St. Petersburg State } \\
\text { Transport University }\end{array}$ & II & 26.6 & 99.9 & 73.7 \\
\hline State Polytechnic University & I & 19.4 & 58.1 & 41.1 \\
\hline Saint Petersburg State University & II & 16.3 & 10.3 & 21.6 \\
\hline $\begin{array}{l}\text { State Chemistry and Pharmaceutical } \\
\text { Academy }\end{array}$ & III & 13.5 & 78.9 & 47.9 \\
\hline Baltic State Technical University & III & 13.1 & 71.8 & 30.1 \\
\hline State Technological Institute & I & 12.9 & 46.3 & 37.4 \\
\hline $\begin{array}{l}\text { State University of Aerospace } \\
\text { Instrumentation }\end{array}$ & I & 12.8 & 68.6 & 47.4 \\
\hline
\end{tabular}

higher the impact on regional and national economies, and the more important the role played by the university in regional society and entrepreneurial culture formation.

The findings also suggest that HEIs with a diversified funding base and higher licensing incomes are those that are regionally integrated, are less focused on internationalization and engage in industry-specific research commercialization activities. A higher share of non-budgetary funding in total income, however, does not correspond with a higher share of research incomes; this suggests that there are still other funding sources, such as tuition fees, charitable contributions, and the funding of university departments. Tier-one and tier-two universities (mostly represented by industry-specific HEIs) fulfill their major function in the regional economy by training skilled graduates for local organizations in maritime, transport, chemical and telecommunication industries; they are generally less concerned with technology transfer and are less engaged in spin-off and licensing activities, with the exception of St. Petersburg State Transport University. Thus, teaching-led universities are more likely to engage with local and regional communities and industries, while tier-one research-intensive HEIs endorse national and international entrepreneurial opportunities (Abreu et al. 2016).

As for tier-one HEIs, budgetary investments do not automatically translate into immediate commercial and measurable outputs. Massive budgetary funding distorts the motivation of universities and academic staff - patents and spin-offs are employed to secure more government funding, while citation and quotation QPIs are likely to shift the focus of selected universities away from commercialization and technology transfer activities (Russian Venture Company 2015). Larger research-intensive universities, though, are major creators of entrepreneurship capital and promoters of entrepreneurial thinking; they have a broader social agenda, are more engaged in informal 
entrepreneurial activities such as conferences, forums, contests and other PR-related activities, and remain major attractors of skilled human capital to the locale.

\section{Conclusion}

Entrepreneurial universities are usually characterized by a diversified funding base, a high research intensity and an international scope of academic activities. This research, however, has yielded a number of compelling findings: a higher academic research intensity, extensive networking activities (including the formation of so-called 'hybrid structures' between universities, industry and state), and an international stance in entrepreneurial universities are usually associated with massive government funding. While there are documented precedents of universities benefitting from generous government support at the initial stages of transforming into entrepreneurial entities, Graham (2014) has found that success metrics employed by policymakers can undermine research quality and mask a very limited contribution of local universities to the entrepreneurial agenda. This contradiction questions the true nature of entrepreneurialism at Russian universities and their ability to sustain one of the key roles in innovation systems at all levels: national, regional and local.

One major caveat to the abovementioned argument is that standard indicators (the number of spin-offs, the number of patents, licensing revenue, etc.) fail to capture the overall economic and innovation impact of entrepreneurial universities (Landström et al. 2015). Quantitative metrics typically act as a gauge of immediate outputs from research activities and innovation infrastructure, while the time horizon required for spin-offs or related commercialization activities to bear fruit extends for years and even decades. This corresponds with Ankrah et al.'s (2012) findings: knowledge and technology transfer stretch beyond tangible and commercial outcomes such as patents or prototypes and include so-called 'intermediate' outputs (ideas, networks, negative findings, etc.).

This paper thus contributes to the broader literature by providing insights into the heterogenous nature of entrepreneurialism at Russian universities and maps various dimensions of entrepreneurial activities undertaken by regional universities. The phenomenon of entrepreneurial universities is multifaceted, and only recently has the policy debate started to acknowledge that university-industry links should also aim at employability solutions for students and academic staff, the promotion of entrepreneurial culture and entrepreneurship-focused education, while less research-intensive universities are becoming more significant for regional innovation and entrepreneurship (Abreu et al. 2016). Less formalized metrics, such as investment in entrepreneurial culture promotion (organizing forums, conferences and workshops, and entrepreneurship courses), the engagement of academic staff and students in entrepreneurial activities and the willingness to collaborate with regional industry and policymakers, are required to capture the entrepreneurial potential of a university (Graham 2014).

It should be noted that this study has some limitations. First, the small sample of observations precludes the type of statistical analysis that would be possible with time series data. The findings can thus be considered exploratory and could be further investigated with a larger sample and more rigorous methods. Second, the findings in this study are based on the unique context of a Russian region with a relatively high level of innovative activity; hence, the conclusions might not hold for other regions, 
especially those with a low level of industrial development, where links between universities and industrial organizations are less dense and mundane. A comparative analysis with mid-range universities in less innovation-intensive regions might therefore open prospects for further research.

Despite these limitations, several policy and managerial implications may be drawn from this research. While contemporary universities might find it hard to establish extensive and durable networks with organizations in traditional industries, more 'affluent' entrepreneurial universities might facilitate the creation of knowledge networks with emergent industries, diffuse academic expertise and provide demand-driven solutions to cater to the needs of industrial organizations in emergent sectors (Freitas et al. 2012).

The evidence provided in this paper also indicates the importance of university teaching and research missions for interaction with industrial partners. It also raises doubts about the direct economic impact of higher education institutions stemming from commercialization and technology transfer. Personal connections with industry and regional entrepreneurial community, however, are critical to the emergence of a university as an entrepreneurial entity, particularly at the initial stages of an institution's entrepreneurial evolution (Graham 2014). Therefore, initiating national and regional programs and policy measures that aim at stimulating the establishment of university-industry links and cater to the financial motives of local firms (co-financing of research projects by government, cutting costs, tax benefits, etc.) would create a market for academic research and innovation and provide a fruitful milieu for entrepreneurial universities.

Data availability The datasets analyzed during the current study are available in the Ministry of Education and the Science of Russian Federation, Informacionnoanaliticheskie materiali po resultatam provedenia monitoringa effectivnosti obrazovatelnih organizacii vishego obrazovania obrazovania [Higher education institutions efficiency monitoring analytical data] repository. http://indicators.miccedu. ru/monitoring/. Accessed 3 June 2017.

Open Access This article is distributed under the terms of the Creative Commons Attribution 4.0 International License (http://creativecommons.org/licenses/by/4.0/), which permits unrestricted use, distribution, and reproduction in any medium, provided you give appropriate credit to the original author(s) and the source, provide a link to the Creative Commons license, and indicate if changes were made.

\section{References}

Abreu, M., Demirel, P., Grinevich, V., \& Karataș-Özkan, M. (2016). Entrepreneurial practices in researchintensive and teaching-led universities. Small Business Economics, 47(3), 695-717.

Allison, J., \& Eversole, R. (2008). A new direction for regional university campuses: Catalyzing innovation in place. Innovation: The European Journal of Social Science Research, 21(2), 95-109.

Ankrah, S., \& Al-Tabbaa, O. (2015). Universities-industry collaboration: A systematic review. Scandinavian Journal of Management, 31(3), 387-408.

Ankrah, S. N., Burgess, T. F., Grimshaw, P., \& Shaw, N. E. (2012). Asking both university and industry actors about their engagement in knowledge transfer: What single-group studies of motives omit. Technovation, $33(2), 50-65$.

Audretsch, D. B. (2014). From the entrepreneurial university to the university for the entrepreneurial society. The Journal of Technology Transfer, 39, 313-321. 
Audretsch, D. B., \& Lehmann, E. E. (2005). Does the knowledge spillover theory of entrepreneurship hold for regions? Research Policy, 34(8), 1191-1202.

Audretsch, D. B., Hülsbeck, M., \& Lehmann, E. E. (2012). Regional competitiveness, university spillovers, and entrepreneurial activity. Small Business Economics, 39(3), 587-601.

Bonander, C., Jakobsson, N., Podestà, F., \& Svensson, M. (2016). Universities as engines for regional growth? Using the synthetic control method to analyze the effects of research universities. Regional Science and Urban Economics, 60(Supplement C), 198-207.

Carree, M., Piergiovanni, R., Santarelli, E., \& Verheul, I. (2015). Factors favoring innovation from a regional perspective: A comparison of patents and trademarks. International Entrepreneurship and Management Journal, 11, 793-810.

Clark, B. R. (1998). Creating entrepreneurial universities. Paris: IAU and. Elsevier Science.

Cowan, R., \& Zinovyeva, N. (2013). University effects on regional innovation. Research Policy, 42(3), 788-800.

Etzkowitz, H. (2016). Innovation Lodestar: the entrepreneurial university in a stellar knowledge firmament. Technological Forecasting and Social Change, 123(Supplement C), 122-129.

Freitas, I. M. B., Marques, R. A., \& Silva, E. M. D. P. E. (2012). University-industry collaboration and innovation in emergent and mature industries in new industrialized countries. Research Policy, 42(2), 443-453.

Graham, R. (2014). Creating university-based entrepreneurial ecosystems: Evidence from emerging world leaders. Massachusetts: Massachusetts Institute of Technology.

Guerrero, M., \& Urbano, D. (2012). The development of an entrepreneurial university. The Journal of Technology Transfer, 37(1), 43-74.

Guerrero, M., Urbano, D., Cunningham, J., \& Organ, D. (2014). Entrepreneurial universities in two European regions: A case study comparison. The Journal of Technology Transfer, 39(3), 415-434.

Huggins, R., \& Kitagawa, F. (2012). Regional policy and university knowledge transfer: Perspectives from devolved regions in the UK. Regional Studies, 46(6), 817-832.

Kempton, L. (2015). Delivering smart specialization in peripheral regions: The role of universities. Regional Studies, Regional Science, 2(1), 489-496.

Kirby, D. A., Guerrero, M., \& Urbano, D. (2011). The theoretical and empirical side of entrepreneurial universities: An institutional approach. Canadia Journal of Administrative Sciences, 28(3), 302-316.

Landström, H., Åström, F., \& Harirchi, G. (2015). Innovation and entrepreneurship studies: One or two fields of research? International Entrepreneurship and Management Journal, 11, 493-509.

Liu, Y. (2012). Does entrepreneurial university really exist in China? A case from Huazhong University of Science and Technology. Journal of Knowledge-based Innovation in China, 4(2), 88-103.

Ramos-Vielba, I., Fernández-Esquinas, M., \& Espinosa-de-los-Monteros, E. (2010). Measuring universityindustry collaboration in a regional innovation system. Scientometrics, 84(3), 649-667.

Russian Venture Company. (2015). Development of innovation ecosystems of HEIs' and scientific centers. Saint-Petersburg: Russian venture company.

Schmitz, A., Urbano, D., Dandolini, G. A., de Souza, J. A., \& Guerrero, M. (2017). Innovation and entrepreneurship in the academic setting: A systematic literature review. International Entrepreneurship and Management Journal, 13, 369-395.

Shattock, M. (2010). The entrepreneurial university: An idea for its time. London Review of Education, 8(3), 263-271.

Taylor, M. P. (2012). The entrepreneurial university in the twenty-first century. London Review of Education, 10(3), 289-305.

Trippl, M., Sinozic, T., \& Smith, H. L. (2015). The role of universities in regional development: Conceptual models and policy institutions in the UK, Sweden and Austria. European Planning Studies, 23(9), 1722-1740.

Urbano, D., \& Guerrero, M. (2013). Entrepreneurial universities. Economic Development Quarterly, 27(1), 40-55.

Yokoyama, K. (2006). Entrepreneurialism in Japanese and UK universities: Governance, management, leadership, and funding. Higher Education, 52, 523-555. 